\title{
THE DIFFICULTIES IN IMPLEMENTING SOCIAL INTERVENTIONS IN THE COMMUNITIES OF FOREIGNERS IN POLAND
}

\author{
KAMILA GANDECKA \\ Institute of Pedagogy, University of Wrocław, \\ Dawida 1, 50-527 Wrocław, Poland \\ E-mail address: kamilagandecka@gmail.com \\ ARKADIUSZ URBANEK \\ Institute of Pedagogy, University of Wrocław, \\ Dawida 1, 50-527 Wrocław, Poland \\ E-mail address: urbanek.arkadiusz@vp.pl
}

\begin{abstract}
The reflections presented in this paper are focused on the problem of the conflict that takes places at the point of contact of two cultures during social interventions in the communities of foreigners residing in Poland. That is why three research perspectives have been presented. The first one is an analysis of the legal solutions pertaining to the acquiring of the status of a legal alien. The second aspect of the research is connected with the features of the institutional forms of social support for foreigners. In the further area the indicators of cultural differences of the investigated group have been discussed and it has been attempted to define the potential areas of conflict. The scientific exploration was aimed to specify to what extent cultural differences condition the process of the foreigners' adaptation to a new socio-cultural reality. Furthermore, an attempt was made to answer the question whether the institutions intended to help foreigners can constitute an area of compromise. For this aim the differences between the levels of expectations represented by the administrative and social services and the foreigners themselves have been shown.
\end{abstract}

Key words: foreigners, social intervention, integration, cultural differences, areas of conflict 


\section{INTRODUCTION}

"A man becomes what others see in him,
which is why it takes enormous courage to defy
stereotypes and fight for one's identity"

(Zelman, 2011, p. 152)

Territorial mobility is a common phenomenon constituting one of the key aspects of human activity, which is why it is a crucial aspect of the historical context of the development of the so-called European civilisation. As Monika Wójcik-Żołądek (2014, p. 11) states: “The moving of populations leads to numerous economic consequences that influence the countries of origin as well as those of destination. Migrations may lead to questioning the heretofore divisions between us and the others, alterations of traditional connections between an individual and a territory, transformations of local communities and their ways of interpreting the world". That is why the multidimensional aspect of migrations as well as their positive and negative consequences condition the assumption of diverse research perspectives. Scholars of numerous fields are interested in international migrations, particularly those of sociology, psychology, pedagogics, political sciences, demographics, geography, economics or history (Wójcik-Żołądek, 2014, p. 11).

Globalisation, armed conflicts, political and religious persecution, as well as the unequal development of different states and regions are the fundamental indicators of the dynamics of migration, especially of people from outside the European Union. The situations of insecurity resulting from non-continuous changes lead to individuals following their survival instincts and making radical decisions. In order to secure better living conditions for themselves and their families they look for a new place to live, they change jobs, and frequently they are forced to run and leave the place where they lived before. Furthermore, it needs to be emphasised that contemporary international migrations are often multiple: the migrants move to various countries a number of times during their lifetime (WójcikŻołądek, 2014, p. 10).

Refugees constitute a specific group within the migrant community. According to UNHCR statistics by the end of 2013 the number of individuals needing protection reached 51.2 million globally. The so-called internal refugees make up a half of this group. They are the people who have left their homes because of persecution, but remain within the boundaries of their home countries. As to the number of refugees remaining outside their home countries it is estimated at 16.7 million, with $70 \%$ (11.7 million) under the UNHCR mandate, and 30\% under the mandate of UNRWA. The last group includes the migrants seeking asylum: their number is estimated at 1.2 million. The European Union has received ca. $43.5 \%$ of all the asylum applications submitted worldwide (Grzymała-Kazłowska, Stefańska, 2014, p. 198; UNHCR-Global Trends, 2013/2014, pp. 2-3). Since 2011 the EU countries where the problems connected with migration and providing international 
help for migrants are the greatest have been Germany, Sweden, Italy, France, Belgium, and the United Kingdom.

Year by year Poland's participation in the international system of protection of foreigners in increasing. These situations are conditioned by, among others, the location of a country, the systematically growing number of aliens seeking international protection ${ }^{1}$, as well as Poland's international commitments, or the changes of refugee policies implemented by other EU countries (e.g. a common approach to managing migration processes, the European asylum system). Under these conditions Poland was forced to develop a separate systems of managing those seeking asylum, as well as those deported and punished. Among the group migrants there were foreigners with refugee status, illegal aliens, and criminals. As of today in multiple areas a coherent approach has not been precisely defined.

A major obstacle in the process of the development of effective legislative and help-related solutions aimed for foreigners seeking international protection is the fact that Poland has substantially fewer traditions and much less experience in this field. Western Europe has been developing legal and interventional solutions since the 1820s. The International Congress of Patrons organised in Paris has issued a citation for France for open migration policies resulting from worldview and the conviction that it is a country that foreigners can be greatly thankful to. At that time such convictions appeared innovative, as well as the solutions pertaining to social intervention. A rational welfare strategy for aliens was connected with granting them support and help in administrative affairs and helping them communicate with officials. Furthermore, cultural support, with its main aim lying in supplementing the knowledge about social relations within the alien population, was also appreciated. These comprehensive solutions became an important area in which mutual understanding and processes of adaptation to the new life could occur (Śliwowski, 1937, pp. 539-540).

After the end of World War II, especially in the 1960s, the subsequent waves of international migration would reach EU member states. The first of them was connected with a major influx of Muslims, particularly from African states (Maghreb), who sought asylum in France. Simultaneously, a large part of the Turkish population reaches Germany, and immigrants from the Indian subcontinent arrive in the UK. The increased mobility of foreigners from outside the EU lasted until the wave of crisis and the Israeli-Egyptian war. That is when the USA and Western European countries took Israel's side. The second wave of migration occurred in 1973-1975 when the process of connecting families gained intensity. Even though originally the immigrants would take into account the necessity of returning to their home coun-

1 According to the statistics of the Agency of Alien Affairs (Urząd do Spraw Cudzoziemców) in the first quarter of 20152.6 thousand asylum applications were submitted in Poland. The biggest groups were the citizens of Russia (47\%) and Ukraine (37\%). What is more, there were also citizens of Georgia (113 applications), Tajikistan (66), Syria (35), and Armenia (26) seeking international protection. Retrieved from: http://udsc.gov.pl/statystyki/raporty-okresowe/ zestawienia-miesieczne/status-uchodzcy/2015-2. 
tries, they would nevertheless aim to settle and remain in their countries of destination. In such situation migration became connected with applications for the legal alien status which, in turn, led to the growing number of marriages in the destination countries. This process lasted until the 1980s. At the turn of the $20^{\text {th }}$ century one can observe the domination of illegal immigration (Islam in the European Union. What is at Stake in the Future?, 2007, p. 8). Today, this tendency remains. It is illustrated by the increasing wave of illegal immigrants arriving in Italy from the African states engulfed in war.

With the European migration processes in the background, Poland has first witnessed the phenomenon of culturally different aliens on a major scale at the onset of the 1990s. The first significant group of foreigners seeking international help arrived in the year 1990. It was a group of approximately one thousand people from African countries who were deported to Poland from Sweden (Rafalik, 2012, p. 5). Subsequently through 1992 to 1993 Poland started to accept refugees from the war-engulfed Balkan states. Bosnian Muslims would arrive first, and in 1999 a large group of immigrants from Kosovo came.

Polish authorities as well as the entire institutional and legal system were completely unprepared for this new situation. A step towards stabilisation and introducing legal order was the signing and subsequent ratification of the Geneva Convention from July 28, 1951 regulating the status of the refugees on September 27, 1991 (Dz. U.,1991, no. 119 pos. 515). The Protocol Relating to the Status of Refugees developed in New York on January 31, 1967 was also signed and ratified (Dz. U., 1991, no. 119 pos. 517). These legal acts constitute the fundamental rules and regulations relating to the treatment of refugees, and they are called international protection. The period between December 16, 1991 and the signing of the European Treaty pertaining to the association with European Communities has also influenced the changes in Polish law relating to refugees by adapting the system to EU regulations (Majdzińska, 2012).

The second wave on the immigration of non-EU citizens into Poland was connected with the war in former Soviet Republics. As a result in 2003 as much as $90 \%$ of all the immigrants residing in Polish refugee centres were the citizens of Chechnya, Dagestan, and Ingushetia (Ząbek, 2012, p. 63). In this period one could witness increased activity in developing legislative and organisational solutions. This was the result of the fact that with the wave of immigrants, especially the culturally different Muslims, numerous problems with the organisation of their stay have appeared. What is more, there were problems in the area of the justice and penitentiary systems, since aliens would more and more frequently be arrested and sentenced for crimes committed in Poland.

This article focuses on the special considerations that apply to social intervention relating to foreigners applying for an international protection in Poland. This is one of particularly vulnerable social group. First of all, they are members of different culture. Secondly, they are participant in a process 
of adaptation to the new socio-cultural reality in specific conditions, which are created by the institutions of the host country. To illustrate the potential areas of conflicts along interfaces between cultures during social interventions, it was necessary to study the Polish legal acts in the field of legalization of stay and to recognize organizational and legal conditions of social assistance for foreigners applying for an international protection in our country. Therefore, it has become possible to determine sources of difficulties in the implementation of social intervention for study group. The main method of the research was document and subject's literature analysis. The selection of source material closely followed the topic outlined in the title of this article. A special place in the source database were legal acts, research reports and statistical data.

\section{LEGAL AND ORGANISATIONAL SOLUTIONS RELATING TO FOREIGNERS}

When developing its policy relating to aliens Poland has the opportunity to observe the actions taken by Western European states and to assess in time how effective and rational they are. What makes it easier is the sense that the approach to working with aliens can be better and more precise and thus make it possible to avoid the problems that scholars in the UK, Germany, and France mentioned. However, on the other hand, is it not illusory that the problems of integration, assimilation, and isolation can be avoided through working on the basis of predictable and clear criteria? The legal and organisational procedures relating to foreigners can less and less frequently be classified, for instance, according to Will Kymlicka's (1995, pp. 30-32) proposition. The aim of multicultural policies is to be integration with the receiving community, and its effect is to be a new social quality. Two currents of multicultural policies are being implemented to achieve the integration results:

- implementation of integration programmes aimed to internalise the values and norms, the language, and the laws of the receiving society,

- granting multiethnic rights intended to preserve aliens' cultural heritage.

Considering social processes only from the perspective of assimilation, integration, or isolation does not exhaust the issues of the conflicts occurring at the point of contact between culturally different communities. When the interests of such communities become intertwined the differences require a further negotiation of principles. And that is why granting multiethnic rights makes it possible to keep a mutual understanding when the representatives of the cultures live within their own environments, enclaves, when they exist separately. When these communities overlap the problem of the importance of rules and principles generates competition. Yet another con- 
text of the approach to working with aliens is the question of the "two-directional integration", which appears to be a counterweight to one-directional acculturation, when the immigrants are forced to - sometimes against their will - to assume the lifestyle and the principles of the nation that receives them. The two-directional character provides the opportunity to preserve religious identity and secures a minimum of opportunities to use one's own laws (Ząbek, 2012, p. 64). But is such an approach realistic and how can one predict its results in the long run? In Poland attempts have been made to negotiate such duality, particularly in relations with Muslims. The Sharia law becomes a competition for the solving of the problems of responsibility for a criminal act which is persecuted under the Polish law, but not under the law of a Muslim state. That is why the two-directional integration is aimed towards the competition between legal systems, with the law of the state on the one hand, and the religious or ethnic law on the other. For Muslims the Sharia law [Sharia is Arabic for a place abundant with water, a source of water (Issa, 2010, p. 20)] is a path of spiritual guidance and eternal life; it is a collection of commandments, prohibitions, guidelines, and rules given by God (Kamali, 2008, p. 121). It is a law that describes and explains, unlike the laws of western countries (Tibi, 2005, pp. 63-64), which are intended to provide clear, unambiguous codifications of existing behaviours and rules, but at the same time attributing divine origins to them discredits the regulations of the law of the state.

The understanding of two-directional integration that is aimed to lead to competition between two legal systems: state and religious or ethnic ones, is a dangerous phenomenon that threatens the idea of multiculturalism. What seems interesting is Maciej Ząbek's statement that multiculturalism ends where different religious and ethnic legal systems are introduced. Furthermore, Chantal Mouffe (2008, pp. 140-141). notices that the conflict of laws leads to more perturbations in the understanding of the philosophy of respect for cultural diversity. That is because the unconditional respect for cultural diversity, so important in European legal tradition, is contrary to the right to be equal, which is also fundamental to democratic societies. The conflict between these democratic ideas can be observed when the interests of different groups are intertwined in everyday relationships, when there is a collision between different principles, norms, and laws. This shows how difficult it is to implement the assumptions of the philosophy of multiculturalism, which is defined immanently with the notions of diversity and mutual respect. According to Paweł Boski (2008, p. 165-205): "Multiculturalism is the coexistence of two or more cultural groups of different distinctive features that conditions the defined type of individual and inter-communal interactions within a culturally diverse society with the simultaneous preservation of the identity of each of the groups. Differences and diversity ought to be affirmed, because each of the cultures has different values to offer others". 


\section{INTEGRATION AND SOCIAL INTERVENTION RELATING TO ALIENS - LEGAL INSTRUMENTS}

An alien residing in Poland who does not hide but tries to legalise their stay is generally subject to procedures resulting from two legal acts: The act on aliens of June 13, 2003 [Ustawa o cudzoziemcach z 13 czerwca 2003 r.] (Dz.U., 2003 , no. 128 , pos. 1175 as amended), and The act on granting aliens protection on the territory of the Republic of Poland of June 13, 2003 [Ustawy o udzielaniu cudzoziemcom ochrony na terytorium RP z 13 czerwca 2003 r.] (Dz.U., 2003, no. 128, pos. 1176 as amended). Among the forms of legalising one's residence on the territory of the Republic of Poland the following need to be listed:

- permit to stay for a defined period of time,

- residence permit,

- long-term European Community residence permit,

- refugee status,

- tolerated residence permit,

- supplementary protection,

- abolition as a chance to legalise the right to work and reside for illegal aliens in Poland.

An important role in the context of social intervention relating to aliens applying for international protection is played by refugee centres organised by the Border Guard. Their character and aims vary, which is why one can differentiate between open and closed (guarded) centres.

Since 2005 an alternative to the refugee status has been provided by the so-called tolerated residence. It can be implemented when forcing an alien to return to their country of origin can put them in danger, as is denoted by, among others: the Geneva Convention (1951), the New York Protocol (1967), and the Rome Convention (1980). Thus, tolerated residence is justified in the following cases:

- when an individual's life, freedom, or safety are in danger;

- when an individual is threatened with forced labour;

- when an individual is threatened with the losing of the right to a fair trial or being punished without legal grounds;

- when an individual is threatened with torture or inhumane treatment.

Additionally, there is a procedure of legalising residence due to humanitarian reasons, which apart from the conditions listed above assumes the necessity of protection in the case when:

- the return to the country of origin could lead to the breaching of a refugees right to family and private life;

- the return would breach children's rights to an extent presenting significant danger to a child's physical and emotional development.

To sum up, both the alternative procedures of granting international protection to aliens (tolerated residence and legalisation of residence due to humanitarian reasons) have an incomparably narrower scope than that of the refugee status. This is confirmed by the fact that tolerated residence does 
not allow one to enrol in the Individual Integration Programme which provides help in integration, welfare, work, education, and healthcare. At the same time, tolerated residence includes limited financial funds devoted to, e.g., learning to speak Polish, and support in finding work and a place to live. Only the Act on welfare makes it possible for aliens with tolerated residence or residence legalised due to humanitarian reasons to benefit from the welfare system by receiving shelter, food, necessary clothing and purposive benefits (art. 5 pt. 2 letter b , Dz. U., 2004, no. 64, pos. 593).

An important obstacle in using the instruments of social intervention in relation to aliens applying for international protection on the territory of the Republic of Poland is the fact that there is not a single institution that could provide aliens with residence longer than a few months. Refugee centres are reception institutions, which means that they allow foreigners to stay for 3 months, that is, until the time when legal decisions are made. Having analysed the case of an alien they can reside in Poland, but without any social support or employment or they have to return to their country of origin. In the case of a negative decision regarding to application for international protection the aliens frequently decide to migrate to Western Europe.

To summarise, the narrow scope of the actions in the area of social support collides with the run of the very process of integration of immigrants into the new social reality. The aforementioned process is relatively long, taking into account acquiring new competences, as well as understanding the new cultural conditionings of the new life in this particular group of immigrants. It is doubtless that such situation is unfavourable from the perspective of general social interests, because aliens without any welfare support are forced to cope by themselves, which is why they are often involved in criminal activities or activities that border on crimes.

"Paradoxically, it may seem that the safest time for an alien is the time when they wait for a decision about their status - "being in the procedure". On the one hand, these are the months of passive suspension, stress caused by the often unpleasant interrogations by the Agency for Alien Affairs, and the frustrating reflecting on what the final decision is going to be. On the other hand, however, it is a time when an alien is provided food and shelter" (Chrzanowska, 2007, p. 240). A further problem is presented by the incoherent standards and quality of services offered by the particular refugee centres; nevertheless, their basic necessities are fulfilled.

\section{IMPLEMENTING SOCIAL INTERVENTION RELATING TO REFUGEES - POTENTIAL AREAS OF CONFLICT}

The difficulties that occur in working with aliens, particularly with refugees, are in part two general problems of different connotations. On the one hand one can observe collisions between interests and norms per- 
taining to everyday life presented in refugee camps as well as in natural situations. The catalogue of the difficulties that are generated by residence in refugee centres results from the different norms of people's behaviour that are represented by diverse cultures. An example is provided by the conflicts between the Muslim community representing the strict rules of the Islamic school of law and the immigrants from former Soviet Republics. Their norms of behaviour pertaining to covering the body or the relations between men and women are fundamentally different, which leads to conflicts with, e.g., immigrants from Chechnya. The mutual hostility results from accusing immigrants from Chechnya of being religious extremists ("wahhabites" is being used as an insult), and they arise from the competition for the domination of rules and habits. An additional source of conflicts is the problems connected with organising everyday life. In this context the reasons for everyday conflicts are, among others, difficulties with maintaining personal hygiene, lack of respect for food (e.g. throwing food away into garbage cans or toilets), improper women's clothing, the way how women from other cultures are being treated (e.g. acts of physical violence).

Yet another important source of conflicts between social workers or officials from the Border Guard and aliens representing the Muslim community is a different view on the role of women as persons occupying dominant positions due to their functions. Female officials guard the legal order and the law in the refugee centre, issue instructions, and carry out consequences for failures to abide. Because of the different views on the social roles of men and women that are based in culture and contrasting these differences leads to clear conflicts. In prisons there is a similar situation. In this area there are also cases of hostility between Muslim inmates and female prison guards (Ząbek, 2012, pp. 67-68).

A second area of conflicts that accompany all the processes of integration and assimilation results from pride and defined roles. That is when the rule of "culture of defiance" is implemented through protests, strikes, and vandalism (Ząbek, 2012, p. 69). This defiance is the effect of the sense that the refugee remains in a subordinate position, without symmetrical relations. The refugee is to submit to requirements and expectations of the receiving society. This is exemplified by the tendency to interfere with changes in lifestyle, especially in the context of childcare (e.g. questions of care, doctor's appointments in the case of illness, vaccinations). The role of social services lies in teaching certain habits connected with childcare which in particular cultural conditions appear to be optimal, but the parents need to learn them and use them. For alien parents these habits are often absolutely strange because they have never seen them before. Unfortunately, the failure to change these habits presents a potential hygienic and epidemiological threat to other children.

It is social services that change the standards of life and traditions of these people and they encourage such behaviour that is accepted in the 
culture of the receiving country. To achieve this, numerous educational and training programmes are implemented and intended for alien minors and their parents. As part of this initiative, social skills training is conducted, especially social communication workshops, as well as workshops on protection from violence and actions connected with social integration and inclusion in employment. To sum up, what lies at the basis of such changes is the necessity to abide. A refugee arriving in Poland needs to quickly learn the culture and the traditions and subsequently they are obliged to abide by the laws and the standards of the new society. However, the research conducted by Aleksandra Chrzanowska and Katarzyna Gracz suggests it is the very obligation that leads to conflicts (Gutkowska, 2007, p. 9).

\section{CONCLUSION}

The problems of immigrants applying for international protection, especially political asylum, are present in various extents in all of Europe. While currently in Poland refugees constitute a minor part of all immigrants, they are a community that is significantly threatened with marginalisation and exclusion. That is why conducting research on this specific social group may broaden the knowledge on the subject of numerous aspects of social and cultural changes in the situation of a contact with them. In this context of the question of recognising potential areas of conflict as well as the definition of the predicators conditioning the processes of adaptation to new socio-cultural conditions and social integration are crucial.

The research conducted on the situation of refugees, particularly on the obstacles and difficulties relating to social intervention and social support, allows one to present reliable information on the majority of society. As a result, comprehensive knowledge in this department may facilitate the readiness of various institutions (including schools, healthcare, units of local administration, police, etc.) for the situation when refugees arrive as petitioners or beneficiaries of certain actions or services.

Undoubtedly refugees are a community with specific needs connected to their difficult experiences in their home countries as well as on their way to the receiving country. Due to their social and legal position they are excluded both from the societies of their home countries and the receiving countries (Czerniejewska, Main, 2008, p. 23). That is why updating the knowledge on the subject of the formal, legal, and social situation of refugees applying for international protection constitutes a crucial condition in the development of effective integration programmes, their evaluation, and improvement. What is connected with this important activity is the recognition and promotion of good practices in providing social support for refugees. 


\section{REFERENCES}

[1] Boski, P. (2008). Wielokulturowość i psychologia dwukulturowej integracji [Multiculturalism and psychology in two-directional integration]. In: H. Mamzer (Ed.), Czy klęska wielokulturowości? [A failure of multicultiralsm?] (pp. 165-205). Poznań: Wydawnictwo Fundacji HUMANIORA.

[2] Chrzanowska, A. (2007). Tożsamość kulturowa uchodźców czeczeńskich [Cultural identity of Chechnyan refugees]. In: A. Gutkowska, K. Gracz (Eds.), Uchodźcy w Polsce. Kulturowo-prawne bariery $w$ procesie adaptacji [Refugees in Poland. Cultural and legal obstacles in the process of adaptation] (pp. 215-348). Warszawa: Stowarzyszenie Integracji Prawnej.

[3] Czerniejewska, I., Main I. (Eds.) (2008). Uchodźcy: Teoria i praktyka [Refugees: Theory and practice]. Poznań: Stowarzyszenie „Jeden Świat”.

[4] Dassetto F., Ferrari S., Maréchal B. (2007). Islam in the European Union. What's at Stake in the Future? Study of European Issa, A.A. Brussels: Policy Department Structural and Cohesion Policies.

[5] United Nations High Commissioner for Refugees (2014). Global Trends 2013. 1-52. Retrieved from: http:// www.unhcr.org/5399a14f9.html.

[6] Grzymała-Kazłowaska, A., Stefańska, R. (2014). Cudzoziemcy korzystający z ochrony w Polsce [Aliens benefitting from protection in Poland]. Studia BAS, 4 (40), 197-222.

[7] Grzymała-Moszczyńska, H. (2000). Uchodźcy. Podręcznik dla osób pracujacych z uchodźcami [Refugees. A coursebook for persons working with refugees]. Kraków: Zakład Wydawniczy "Nomos".

[8] Kamali, M.H. (2008). Shari'ah Law. An Introduction. Oxford: One World.

[9] Kymlicka, W. (1995). Multicultural Citizenship. A Liberal Theory of Minority Right. Oxford: Clarendon Press.

[10] Majdzińska, K. (2012). Trudności w integracji cudzoziemców, którzy uzyskali w Rzeczypospolitej Polskiej status uchodźcy lub ochrone uzupetniajaca [Difficulties in the integration of aliens who have achieved the status of refugees or supplementary protection in the Republic of Poland]. Warszawa: Europejski Fundusz Społeczny.

[11] Mouffe, Ch. (2008). Polityczność. Przewodnik krytyki politycznej [Political character. Guidebook of political criticism]. Warszawa: Wydawnictwo Krytyki Politycznej.

[12] Rafalik, M. (2012), Cudzoziemcy ubiegajacy się o nadanie statusu uchodźcy w Polsce - teoria a rzeczywistość (praktyka) [Aliens applying for the refugee status in Poland: theory and reality (practice)] (legal situation as of 31 December, 2011 r.). Warszawa: Ośrodek Badań nad Migracjami Uniwersytetu Warszawskiego.

[13] Szari'a: zamiar i cele w prawodawstwie muzułmańskim [Sharia: intentions and aims in Muslim law] (2010). Al-salam. Muzutmańskie czasopismo społeczno-kulturalne, 1 (19), 11-15, 20-24.

[14] Śliwowski, J. W. (1937). Międzynarodowy Kongres Patronatów w Paryżu [International Congress of Patrons in Paris. Polish Penitentiary Review]. Przeglad Więziennictwa Polskiego, 3, $536-552$.

[15] Tibi, B. (2005). Islam between Culture and Politics. Basingstoke: Palgrave Macmillan.

[16] Wójcik-Żołądek, M. (2014). Współczesne procesy migracyjne: definicje, tendencje, teorie [Contemporary migration processes: definitions, tendencies, theories]. Studia BAS, 4 (40), 9-35.

[17] Ząbek, M. (2012), Problemy integracji uchodźców muzutmańskich w Polsce [Problems of the integration of Muslim refugees in Poland]. In: M. Widy-Behiesse (Ed.), Islam w Europie. Bogactwo różnorodności czy źródło konfliktów? [Islam in Europe. Richness of diversity or a source of conflict] (pp. 63-71). Warszawa: Wydawnictwo Akademickie DIALOG.

[18] Zelman, L H. (2011). Tożsamość anioła [Identity of an angel]. Warszawa: Wydawnictwa Nasza Księgarnia. 